\title{
IMPACT OF INDUSTRIES ON GROUND WATER QUALITY BY COMPARISON BETWEEN HOSHANGABAD (NON INDUSTRIAL AREA) AND MANDIDEEP (INDUSTRIAL AREA), BHOPAL (INDIA)
}

\author{
Abhishek Mandloi ${ }^{1}$

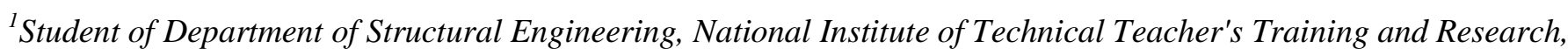 \\ Bhopal
}

\begin{abstract}
India is a developing country, so the industrialization is increasing day by day. Industrialization shows the growth of country but these industries also effects the ground water quality, in a direct manner as well as indirect manner. My case study aim to show impact of industries on ground water quality by comparison between an industrial (Mandideep) and non-industrial (Hoshangabad) area. For this, four different source of different locations are selected for analyzing the parameter $\mathrm{pH}$, Total Hardness, Sulphate,Chloride, Dissolved Oxygen (DO), T.D.S., T.H., T.A ,compared theses result to WHO and ISI standards and also these parameters compared between both the cities.
\end{abstract}

Keywords: Ground water quality, Pollution, Lake

\section{INTRODUCTION}

Over two third area of Earth covered by water and left one third taken up by land. Water is in such a very rich proportion present on our planet but the conservation of this water bodies in a pure form is the basic and very important need of whole world.

India is a developing country. Its population around 1.252 billion according to 2013 census, for this population availability and supply of potable water is very major challenge for us. In India the major source of drinking water is running river, lakes and in some rural areas wells and hand pumps are also the source of drinking water, but due to rapidly increase in population, industrialization, urbanization, technology development and access use of chemicals in agriculture, are the major source of water pollution. These source dispose waste water directly to running stream without any treatment thus decrease in potability of water.

\section{STUDY AREA}

Mandideep lies between $23^{\circ} 5^{\prime} 40^{\prime \prime} \mathrm{N} 77^{\circ} 31^{\prime} 5^{\prime \prime} \mathrm{E}$. Mandideep is a municipality in Goharganj sub-district of raisen district. It is an Industrial area near Bhopal at distance $32 \mathrm{~km}$. It has number of large and small industries some of major industries are Hindustan Electro Graphite (HEG), Procter \& Gamble, Eicher tractor Ltd. , Lupin laboratries. This industrial area boasts turnover of Rs. 1700 crore and revenue of Rs. 1400 crore in the form of various taxes such as central excise, commercial tax, income-tax, property tax, etc.
Hoshangabad lies between the parallels of $\mathbf{2 2}^{\circ} \mathbf{7 5 ^ { \prime }} \mathrm{N} 77^{\circ} \mathbf{7 2} \mathbf{E}$. In Hoshangabad district, there are two main rivers namely the Narmada and the Tawa. A very big lake is also at Pachmarhi, which is one of the main tourist place of the district. Hoshangabad is a very rich district for agriculture because of prencese of "Black cotton soil" at many of land area. It is totally an agricultural area, but only a two industry (Security Paper Mill Hoshangabad) is situated away to the city and Vardhman textile industry.

Mandideep has mainly chemical electro graphite dyes, plastic and rubber Industrial units. Most of these industries produce waste containing toxic heavy metals along with hazardous organic and inorganic effluents; these chemicals contaminate ground water while in Hoshangabad only water is polluted due to only improper drainage in some regions.

\section{MATERIAL AND METHODS}

The main objective of surface water quality monitoring is to assess the existing level of ground water pollution and give an idea about the impact of industry on natural ground water sources. On the basis of preliminary survey of the study area, four numbers of sampling location with different sources of water were selected in both the cities.

In order to assess the ground water samples quality water samples were collected from these sampling stations during financial year 2014. The sampling stations and locations are given in table-1 and table -2. 
Table 1: Sampling stations and locations (Mandideep)

\begin{tabular}{|l|l|}
\hline Source & Location \\
\hline $\mathrm{S}_{1}$-Tubewell & Bisankheda \\
\hline $\mathrm{S}_{2}$-Tubewell & HEG \\
\hline $\mathrm{S}_{3}$-Municipal water & Indus Township \\
\hline $\mathrm{S}_{4}$-Handpump & Nayapura \\
\hline
\end{tabular}

Table 2: Sampling stations and locations (Hoshangabad)

\begin{tabular}{|l|l|}
\hline Source & Location \\
\hline$S_{1}$-Tubewell & Vardhman \\
\hline$S_{2}$-Municipal water & Rashuliya \\
\hline$S_{3^{-}}$Handpump & Hanumangarh \\
\hline$S_{4}$ - Handpump & Adamgarh \\
\hline
\end{tabular}

\section{PARAMETERS ANALYZED}

Following parameters were analysed during the course of study

\section{$4.1 \mathrm{pH}$}

The hydrogen ion concentration is the indicator of acidity and alkalinity of any aqueous system. During present investigation $\mathrm{pH}$ was measured with the help of a $\mathrm{pH}$ meter

\subsection{Turbidity}

Turbidity was determined with the help of Nephalo Metric Turbidity Tube. The results are expressed as Nephalometric Turbidity Unit (NTU).

\subsection{Dissolved Oxygen}

Dissolved oxygen was analyzed by Winkler's method with azide modification following the description given in APHA.

\subsection{Total Dissolved Solids}

T.D.S. was measured using the electronic TDS meter (ELE) and was reported as $\mathrm{mg} / \mathrm{l}$ or parts per million (ppm).

\subsection{Total Alkalinity}

T.A. was measured by titrating the water sample with sulphuric acid of known value of $\mathrm{pH}$, volume and concentration.

\subsection{Total Hardness}

T.H. was measured by buffered the water sample to $\mathrm{pH} 10.1$ and taken in to a conical flask and indicator EBT is added to solution containing calcium and magnesium ions, the color of the solution turns wine red.

\subsection{Sulphate}

$\mathrm{SO}_{4}{ }^{2-}$ was measured first mixed water sample with $\mathrm{BaCl}_{2}$ and then sample is analysis by spectrometer at $420 \mathrm{~mm}$ and sulphate ion determined by standard curve given in APHA 20 th edition method $4500 \mathrm{E}$.

\subsection{Chloride}

$\mathrm{Cl}^{-}$was measuring by titrating water sample by silver nitrate solution as per IS 3025 (Part 32).

The water sample were collected in plastic canes of 3 liter capacity as per standard procedure

\section{RESULTS}

The average value of chemical parameters during financial year 2013, are presented in table 3 and table 4 . The values obtained were compared with standard value prescribed by WHO and ISI-10500-91.

The PH values varied between 6.6 to 7.4 in both the area and found within the prescribed limit suggested by W.H.O. T.D.S. values in Mandideep area varied from 121 to 1725 $\mathrm{mg} / \mathrm{l}$. It shows that sample S1 and S2 have higher values than the prescribed limit given by ISI $10500-91$ but in Hoshangabad area T.D.S. value varies 163 to $550 \mathrm{mg} / \mathrm{l}$. It clearly indicate the impact of industry waste on the water quality in Mandideep area.

Similarly D.O. values.in Mandideep areavaried between 4.9 to 7.1. It shows higher value (sample $\mathrm{S} 1$ and $\mathrm{S} 2$ ) than prescribed limit given by ISI 10500-91, also in Hoshangabad (near vardhman factory) area, its little more than ISI 10500-91.

In the present study the turbidity values in both the areas varies between 3.4 to 6.2 , N.T.U and found within the prescribed limit

Total alkalinity values for tube well samples taken in both the area were found to be greater than the prescribed limit by ISI 10500-91. Total hardness values for tube well samples were found to be greater than prescribed limit by ISI 10500-91 in Hoshangabad (near the factory) as well in Mandideep area.

The Chloride values for tube well samples taken in Mandideep area were found greater than prescribed limit by ISI 10500-91, but in Hoshangabad area it is in limit Prescribed by ISI 10500-91.

The sulphate values in both the area varies from 41.93 to $99.00 \mathrm{mg} / \mathrm{l}$ and was found within the prescribed limit.

\section{CONCLUSION}

This case study clearly shows that the ground water in the study of area exceeded the prescribed limit of Total dissolved solids, Total Hardness, Total alkalinity and chlorides limits prescribed by ISI -10500 (1991) at sampling station $S(1)$ and $S(2)$ in Mandideeep area while in Hoshagabad area the value of T.D.S, T.H., T.A., chloride, sulphate, Turbidity are within limit as prescribed in ISI10500(1991). 
On the basis of experiment carried out it may be stated that the quality of tube well water is inferior as compared to Hand pump and Municipal water. It may be due to impact of industrial and domestic effluents. Such high values will have negative impacts on the health of Human beings residing in that area, judiously the corrective measures should be adopted to prevent increase of Chemical parameter in ground water in Mandideep area to safe guard public health while in Hoshangabad has a safe drinking water for public health without any treatment.

\section{REFERENCES}

[1] Tanner, C. C., Clayton, J.S., and Upsdell, M. P.; Effect of loading rate and planting on treatment of dairy farm wastewater in constructed II. Removal of nitrogen and phosphorus. Water Research. 29: 27-34 (1995b).

[2] Tshobanoglous G and Culp, G.L.; Wetland Systems for Wastewater Treatment: An Engineering Assessment. US Environmental Protection Agency, Office of Water Programme Operations, Series Water EPA 430/9-80-007, Washington DC. (1980).
[3] Gersberg, R.M., Elkins, B.V., Lyon, S.R., and Goldman, C.R; Role of aquatic plants in wastewater treatment by artificial wetlands, Water Research, 20: 363-368. (1986).

[4] Iqbal S. A., Khan S.S., Chaghtai S. A. and Irfan Husain; Assesment of pollution levels of river Betwa, J. Sci. Res., 6(3): 165 -170 (1984).

[5] WHO, world Health Organisation International Standard for Drinking Water, Geneva, Swizerland (1993).

[6] Indian Standard Specification for Drinking Water, ISI, New Delhi (1991).

Table 3: Ground water quality from the study area ( Mandideep industrial area) with drinking water standard

\begin{tabular}{|l|l|l|l|l|l|l|l|l|l|}
\hline $\begin{array}{l}\text { S. } \\
\text { No }\end{array}$ & Paremeters & \multicolumn{1}{|c|}{$\mathbf{S}_{\mathbf{1}}$} & \multicolumn{1}{|c|}{$\mathbf{S}_{\mathbf{2}}$} & \multicolumn{1}{|c|}{$\mathbf{S}_{\mathbf{3}}$} & \multicolumn{1}{|c|}{$\mathbf{S}_{\mathbf{4}}$} & \multicolumn{2}{|c|}{ W.H.O.1993 } & \multicolumn{2}{|c|}{ ISI 10500-91 } \\
\hline & & & & & & Min. & Max. & & \\
\hline 1. & PH & 6.6 & 7.1 & 7.1 & 7.4 & 6.7 & 7.7 & $6.5-8.5$ & $7.8-5$ \\
\hline 2. & T.D.S & 1725 & 490 & 100 & 121 & 160 & 1080 & 1000 & 500 \\
\hline 3. & Turbidity & 5.1 & 5.1 & 3.4 & 6.2 & 3.8 & 8.6 & - & 10 \\
\hline 4. & D.O. & 4.1 & 3.5 & 7.1 & 3.5 & 2.7 & 8.2 & - & 5.0 \\
\hline 5. & T.A. & 305 & 550 & 125 & 145 & 140 & 614 & 120 & 200 \\
\hline 6. & T.H. & 721 & 610 & 154 & 209 & 168 & 923 & 500 & 300 \\
\hline 7. & $\mathrm{Cl}^{-}$ & 455.0 & 190.00 & 170 & 125 & 69.02 & 477.5 & 250 & 250 \\
\hline 8. & $\mathrm{SO}_{4}{ }^{2-}$ & 99.00 & 53.00 & 50.79 & 41.53 & 39.73 & 93.39 & 250 & 200 \\
\hline
\end{tabular}

Table 4: Ground water quality from the study area (Hoshangabad area) with drinking water standards

\begin{tabular}{|l|l|l|l|l|l|l|l|l|l|}
\hline $\begin{array}{l}\text { S. } \\
\text { No }\end{array}$ & Paremeters & \multicolumn{1}{|c|}{$\mathbf{S}_{\mathbf{1}}$} & \multicolumn{1}{|c|}{$\mathbf{S}_{\mathbf{2}}$} & \multicolumn{1}{|c|}{$\mathbf{S}_{\mathbf{3}}$} & \multicolumn{1}{|c|}{$\mathbf{S}_{\mathbf{4}}$} & \multicolumn{2}{|c|}{ W.H.O.1993 } & \multicolumn{2}{c|}{ ISI 10500-91 } \\
\hline & & & & & & Min. & Max. & & \\
\hline 1. & PH & 6.5 & 7.0 & 6.9 & 7.6 & 6.7 & 7.7 & $6.5-8.5$ & $7.8-5$ \\
\hline 2. & T.D.S & 550 & 450 & 163 & 165 & 160 & 1080 & 1000 & 500 \\
\hline 3. & Turbidity & 5.0 & 6.0 & 5.7 & 7.5 & 3.8 & 8.6 & - & 10 \\
\hline 4. & D.O. & 5.1 & 7.1 & 6.5 & 4.9 & 2.7 & 8.2 & - & 5.0 \\
\hline 5. & T.A. & 175 & 155 & 110 & 175 & 140 & 614 & 120 & 200 \\
\hline 6. & T.H. & 345 & 192 & 185 & 190 & 168 & 923 & 500 & 300 \\
\hline 7. & $\mathrm{Cl}^{-}$ & 155.0 & 100.52 & 95.01 & 102.3 & 69.02 & 477.5 & 250 & 250 \\
\hline 8. & $\mathrm{SO}_{4}{ }^{2-}$ & 51.00 & 49.20 & 40.23 & 41.25 & 39.73 & 93.39 & 250 & 200 \\
\hline
\end{tabular}

